\title{
Paratyphoid fever in Thai children: an eleven-year experience
}

Chitsanu Pancharoen, Usa Thisyakorn

\begin{abstract}
Abstrak
Telah dipelajari demam paratifoid pada anak-anak di RS Chulalongkorn, Bangkok, Thailand sebanyak 22 kasus kultur positif Salmonella paratyphi A terdiri dari 13 kasus wabah tahun 1986-1995 dan 9 kasus wabah tahun 1996. Anak laki-laki lebih sering terkena, dan pada umur sekitar 6 bulan-14 tahun. Gejala yang utama termasuk: demam dengan rata-rata 9,6 hari, gangguan gastrointestinal, terutama hepatomegali, muntah, anoreksia, nyeri abdomen, perut kembung, dan diare. Hampir semua pasien menunjukkan nilai hematokrit normal, hitung jenis lekosit 5000-9000 sel/ $\mathrm{mm}^{3}$ dan persentase neutrofil 33-88. Empat pasien mengalami komplikasi, dua di antaranya mengalami kelainan jantung: perikarditis dan endokarditis. Semua isolat kuman sensitif terhadap kotrimoksasol, ampisilin, kloramfenikol dan seftriakson yang diukur dengan menggunakan metode difusi cakram. Antibiotika diberikan sampai 20 hari, dan panas turun setelah 2-8 hari pengobatan. Tidak terjadi kematian pada kasus-kasus tersebut.
\end{abstract}

\begin{abstract}
To study children with paratyphoid fever at Chulalongkom Hospital, Bangkok, Thailand, twenty-two cases of hemoculture-proved Salmonella paratyphi A were studied: 13 cases during 1986-1995 and 9 cases during the outbreak in 1996. Boys were affected more commonly and the age range was between 6 months and 14 years. Major presentations included fever with the average duration of 9.6 days, and gastrointestinal manifestations, mainly hepatomegaly, vomiting, anorexia, abdominal pain, abdominal distension and diarrhea. Most patients had normal hematocrit value, white blood cell count of 5,000-9,000 cells $/ \mathrm{mm} 3$ and percent neutrophils of 33-88. Four patients had complications, with two rarely reported cardiac involvement including pericarditis and endocarditis. All tested isolates were sensitive to cotrimoxazole, ampicillin, chloramphenicol and ceftriaxone by disk-diffusion method. Different antibiotic regimes were used for up to twenty days with subsidence of fever within 2-11 days after treatment. There was no mortality.
\end{abstract}

\section{INTRODUCTION}

Enteric fever remains a serious health problem in many regions of the world. The etiologic agents are Salmonella typhi, causing typhoid fever and Salmonella paratyphi $A, B$ and $C$, causing paratyphoid fever. The latter disease was relatively uncommon in Thailand. However, in 1996 there was an outbreak of Salmonella paratyphi $A$ infections in Bangkok. This study was conducted to determine the natural history of paratyphoid fever in Thai children during a 10year period and in 1996 during the outbreak.

\section{PATIENTS AND METHODS}

The medical records of all children treated at Chulalongkorn Hospital between 1986 and 1996 who were diagnosed as having enteric fever and a positive blood culture of Salmonella paratyphi were reviewed. We studied demographic data, clinical manifestations, laboratory findings, treatment and outcome.

Department of Pediatrics, Faculty of Medicine,

Chulalongkorn University, Bangkok, Thailand

\section{RESULTS}

\section{Demographic data}

Of 22 children with positive blood culture of Salmonella paratyphi, there were 13 boys and 9 girls, with age range between 6 months and 14 years and the average age of 8.3 years. Seventy-five percent of study patients were five years of age or older.

\section{Clinical Manifestations}

Symptoms included fever (100\%) with average duration of 9.6 days, gastrointestinal symptoms $(87.5 \%)$ comprising of vomiting $(62.5 \%)$ anorexia $(50 \%) \mathrm{di}-$ arrhea (31.3\%), abdominal pain (31.3\%) constipation $(6.3 \%)$, cough $(37.5 \%)$, drowsiness $(18.8 \%)$, chills $(18.8 \%)$ and sore throat $(18.8 \%)$. Signs included hepatomegaly $(75 \%)$, splenomegaly $(18.8 \%)$, abdominal distension (12.5\%), "toxic looking" appearance $(6.3 \%)$ and rales $(6.3 \%)$.

\section{Complications}

Four patients developed complications including pneumonitis (2), endocarditis (1) and pericarditis (1). Details of the last two patients are described below. 


\section{Laboratory Findings}

The majority of patients had normal hematocrit level, white blood cell count of 5,000-9,000 cells $/ \mathrm{mm} 3$ with the range of neutrophiles from 33 to 88 percent.

All isolated strains were Salmonella paratyphi A. Susceptibility test using disk diffusion method revealed 100 percent sensitivity to all six drugs commonly used: cotrimoxazole, ampicillin, chloramphenicol, ceftriaxone, ciprofloxacin and imipenen.

\section{Treatment and outcome}

Different antibiotic regimes were used for up to twenty days. Common drugs used included ampicillin and cotrimoxazole. The response of fever declination was 2-11 days after treatment. Three patients did not receive antibiotics. There was no mortality.

\section{Patient 1}

An eight-year-old boy, underlying Tetralogy of Fallot (tof), presented with ten days of fever, headache and vomiting. Physical examination revealed high fever, cyanosis, heart murmur and clubbing of fingers. High hematocrit with normal white blood cell and platelet counts were observed. Echocardiogram was compatible with TOF and revealed $0.7 \times 0.7$ centimeters vegetation. Hemoculture showed Salmonella paratyphi A in three out of four specimens. Ampicillin was used and was eventually changed to cefotaxime after the appearance of rash, indicating ampicillin allergy.

\section{Patient 2}

An eleven-year-old boy, underlying atrial septal defect, patent ductus arteriosus and tricuspid insufficiency, presented with prolonged fever and vomiting for three weeks. One week prior to admission, he was dyspneic. Physical examination showed heart murmurs, pericardial rub and hepatomegaly, without evidence of embolic phenomenon. Mild leukocytosis without left shifting was noticed. Chest $\mathrm{x}$-ray suggested pulmonary congestion and enlargement of cardiac shadow. Echocardiogram disclosed pericardial effusion without vegetation. Inotropic drugs, diuretic and erythromycin were given. Hemoculture revealed Salmonella paratyphi $A$, sensitive to ampicillin and cotrimoxazole in four out of five specimens. Paratyphoid fever with pericarditis was diagnosed. Intravenous ampicillin was used with successful outcome.

\section{DISCUSSION}

Thisyakorn U, Mansuwan P and Taylor DN in 19871 reviewed 29 children with paratyphoid fever in Children's Hospital, Bangkok, Thailand between 1977 and 1984. Most children studied and in our study presented with prolonged fever and gastrointestinal manifestations. Cough was found approximately 40 percent in both studies. The susceptibilities to cotrimoxazole and ampicillin were 99 and 82 percent respectively whereas all tested strains in our study were sensitive to ampicillin, chloramphenicol, cotrimoxazole, ceftriaxone, ciprofloxacin and imipenem. Therefore, any out of the first four mentioned antibiotics can be selected.

There was an outbreak of Salmonella paratyphi A infections in Bangkok in 1996. Most patients were middle to upper class adolescents and young adults, with significant history of fast food consumptions. There was, however, a limited number of infected children.

In our study, two patients had relatively rare cardiac complications including one patient with endocarditis and the other with pericarditis.

Salmonella endocarditis was not common. Saphra I and Winter JW in 19572 reported 20 cases of endocarditis among 7,779 cases of salmonella infections and none of these was caused by Salmonella paratyphi. Previous literature reports and reviews ${ }^{2-9}$ showed that there were only four cases of endocarditis caused by Salmonella paratyphi. Of these, only one was a pediatric case aged 11 months.

Salmonella pericarditis was also an uncommon entity. Haggman DL, Rehm SJ, Moodie DS and Mackenzie AH in 198610 reviewed 23 cases of nontyphoidal salmonella pericarditis between 1936-1986 and four of these were caused by Salmonella paratyphi. In 1990 there was a reported case of salmonella pericarditis caused by Salmonella paratyphi $A$ in a 23year-old female with underlying Systemic Lupus Erythematosus (SLE) ${ }^{11}$.

Paratyphoid fever was relatively uncommon in Thai children between 1986 and 1995 until the outbreak in Bangkok in 1996. Most cases presented with fever and gasirointestinal manifestations. All tested isolates were sensitive to cotrimoxazole, ampicillin, chloramphenicol and ceftriaxone. Two children with rare cardiac complications were reported during this outbreak. 


\section{REFERENCES}

1. Thisyakorn U, Mansuwan P, Taylor DN. Typhoid and paratyphoid fever in 192 hospitalized children in Thailand. Amer J Dis Child 1987; 141: 862-5.

2. Saphra I, Winter JW. Clinical manifestations of salmonellosis in man - an evaluation of 7,779 human infections identified at the New York Salmonella Centre. N Engl J Med 1957; 256:1128-34.

3. Schneider PJ, Nernoff LTJ, Gold JA. Acute salmonella endocarditis: report of a case and review. Arch Intern Med 1967; 120: $478-82$

4. Cohen PS, Maguire JH, Weinstein L. Infective endocarditis caused by gram-negative bacteria: a review of the literature, 1945-1977. Prog Cardio Dis 1980; 22: 205.

5. Suwangool S, Silpapojakul K. Salmonella endocarditis: report of two cases. J Infect Dis Antimicrob Agent 1987; 4: 637

6. Cohen JI, Bartlett JA, Corey GR. Extra-intestinal manifesta- tions of salmonella infections. Medicine 1987, 66: 349-55.

7. Guerrero MLF, Perea RT, Rodrigo JG. Infective endocarditis due to non-typhi salmonella in-patients infected with human immunodeficiency virus: report of two cases and review. Cli Infect Dis 1996; 22: 853-5.

8. Johnson DH, Rosenthal A, Nadas AS. Bacterial endocarditis in children under 2 years of age. Amer J Dis Child 1975; 129: $183-6$.

9. Gupta S, Singh B, Kapoor H, et al. Ventricular septal defect with endocarditis caused by Salmonella paratyphi A. Trop Doc 1994; 24: 40

10. Haggman DL, Rehm SJ, Moodie DS, Mackenzie AH. Nontyphoidal salmonella pericarditis: a case report and review of the literature. Pediatr Infect Dis 1986; 5: 259-64.

11. Guerrero JS, Segovia DA. Salmonella pericarditis with tamponade in Systemic Lupus Erythematosus. Bri J Rheu 1990; 29: 69-71. 